\title{
High-fat diets rich in medium- versus long-chain fatty acids induce distinct patterns of tissue specific insulin resistance.
}

Citation for published version (APA):

de Vogel-van den Bosch, J., van den Berg, S. A., Bijland, S., Voshol, P. J., Havekes, L. M., Romijn, H. A., Hoeks, J., Van Beurden, D., Hesselink, M. K. C., Schrauwen, P., \& van Dijk, K. W. (2011). High-fat diets rich in medium- versus long-chain fatty acids induce distinct patterns of tissue specific insulin resistance. Journal of Nutritional Biochemistry, 22(4), 366-371. https://doi.org/10.1016/j.jnutbio.2010.03.004

Document status and date:

Published: 01/04/2011

DOI:

10.1016/j.jnutbio.2010.03.004

Document Version:

Publisher's PDF, also known as Version of record

Document license:

Taverne

Please check the document version of this publication:

- A submitted manuscript is the version of the article upon submission and before peer-review. There can be important differences between the submitted version and the official published version of record.

People interested in the research are advised to contact the author for the final version of the publication, or visit the DOI to the publisher's website.

- The final author version and the galley proof are versions of the publication after peer review.

- The final published version features the final layout of the paper including the volume, issue and page numbers.

Link to publication

\footnotetext{
General rights rights.

- You may freely distribute the URL identifying the publication in the public portal. please follow below link for the End User Agreement:

www.umlib.nl/taverne-license

Take down policy

If you believe that this document breaches copyright please contact us at:

repository@maastrichtuniversity.nl

providing details and we will investigate your claim.
}

Copyright and moral rights for the publications made accessible in the public portal are retained by the authors and/or other copyright owners and it is a condition of accessing publications that users recognise and abide by the legal requirements associated with these

- Users may download and print one copy of any publication from the public portal for the purpose of private study or research.

- You may not further distribute the material or use it for any profit-making activity or commercial gain

If the publication is distributed under the terms of Article $25 \mathrm{fa}$ of the Dutch Copyright Act, indicated by the "Taverne" license above, 


\title{
High-fat diets rich in medium- versus long-chain fatty acids induce distinct patterns of tissue specific insulin resistance ${ }^{2}$
}

\author{
Johan De Vogel-van den Bosch ${ }^{\mathrm{a}, \mathrm{b}, 1}$, Sjoerd A.A. van den Berg ${ }^{\mathrm{a}, \mathrm{d}, 1}$, Silvia Bijland ${ }^{\mathrm{d}}$, Peter J. Voshol ${ }^{\mathrm{e}}$, \\ Louis M. Havekes, ${ }^{\mathrm{f}, \mathrm{h}, \mathrm{h}}$, Hans A. Romijn ${ }^{\mathrm{e}}$, Joris Hoeks ${ }^{\mathrm{b}}$, Denis van Beurden ${ }^{\mathrm{a}, \mathrm{b}}$, Matthijs K.C. Hesselink ${ }^{\mathrm{c}}$, \\ Patrick Schrauwen ${ }^{\mathrm{a}, \mathrm{b}}$, Ko Willems van Dijk ${ }^{\mathrm{a}, \mathrm{d}, \mathrm{f}, *}$ \\ ${ }^{\mathrm{a}}$ Top Institute Food and Nutrition, 6700 AN Wageningen, The Netherlands \\ ${ }^{\mathrm{b}}$ Department of Human Biology, Maastricht University Medical Center+, 6229 ER Maastricht, The Netherlands \\ ${ }^{\mathrm{c}}$ Department of Human Movement Sciences, Maastricht University Medical Center +, 6229 ER Maastricht, The Netherlands \\ ${ }^{\mathrm{d}}$ Department of Human Genetics, Leiden University Medical Center, 2300 RC Leiden, The Netherlands \\ ${ }^{\mathrm{e}}$ Department of Endocrinology and Metabolic Diseases, Leiden University Medical Center, 2300 RC Leiden, The Netherlands \\ ${ }^{\mathrm{f}}$ Department of General Internal Medicine, Leiden University Medical Center, 2300 RC Leiden, The Netherlands \\ ${ }^{\mathrm{g}}$ The Netherlands Organization for Applied Scientific Research - BioSciences, Gaubius Laboratory, 2333 CK Leiden, The Netherlands \\ ${ }^{\mathrm{h}}$ Department of Cardiology, Leiden University Medical Center, 2300 RC, Leiden, The Netherlands.
}

Received 10 September 2009; received in revised form 25 February 2010; accepted 4 March 2010

\begin{abstract}
Excess dietary long-chain fatty acid (LCFA) intake results in ectopic lipid accumulation and insulin resistance. Since medium-chain fatty acids (MCFA) are preferentially oxidized over LCFA, we hypothesized that diets rich in MCFA result in a lower ectopic lipid accumulation and insulin resistance compared to diets rich in LCFA. Feeding mice high-fat (HF) (45\% kcal fat) diets for 8 weeks rich in triacylglycerols composed of MCFA (HFMCT) or LCFA (HFLCT) revealed a lower body weight gain in the HFMCT-fed mice. Indirect calorimetry revealed higher fat oxidation on HFMCT compared to HFLCT $(0.011 .0 \pm 0.0007$ vs. $0.0096 \pm 0.0015 \mathrm{kcal} / \mathrm{g}$ body weight per hour, $P<.05)$. In line with this, neutral lipid immunohistochemistry revealed significantly lower lipid storage in skeletal muscle $(0.05 \pm 0.08$ vs. $0.30 \pm 0.23$ area\%, $P<.05)$ and in liver $(0.9 \pm 0.4$ vs. $6.4 \pm 0.8$ area\%, $P<.05)$ after HFMCT vs. HFLCT, while ectopic fat storage in low fat (LF) was very low. Hyperinsulinemic euglycemic clamps revealed that the HFMCT and HFLCT resulted in severe whole body insulin resistance (glucose infusion rate: $53.1 \pm 6.8,50.8 \pm 15.3$ vs. $124.6 \pm 25.4 \mu \mathrm{mol} \mathrm{min} \mathrm{m}^{-1} \mathrm{~kg}^{-1}, P<.001$ in HFMCT, HFLCT and LF-fed mice, respectively). However, under hyperinsulinemic conditions, HFMCT revealed a lower endogenous glucose output (22.6 \pm 8.0 vs. $\left.34.7 \pm 8.5 \mu \mathrm{mol} \mathrm{min}^{-1} \mathrm{~kg}^{-1}, P<.05\right)$ and a lower peripheral glucose disappearance ( $75.7 \pm 7.8$ vs. $93.4 \pm 12.4 \mu \mathrm{mol} \mathrm{min} \mathrm{m}^{-1} \mathrm{~kg}^{-1}, P<.03$ ) compared to HFLCT-fed mice. In conclusion, both HF diets induced whole body insulin resistance compared to LF. However, the HFMCT gained less weight, had less ectopic lipid accumulation, while peripheral insulin resistance was more pronounced compared to HFLCT. This suggests that HF-diets rich in medium- versus long-chain triacylglycerols induce insulin resistance via distinct mechanisms. (c) 2011 Elsevier Inc. All rights reserved.
\end{abstract}

\section{Introduction}

Insulin resistance plays a key role in the pathogenesis of Type 2 diabetes mellitus and other metabolic disorders such as obesity and hypertension [1]. Insulin resistance is characterized by the reduced

Abbreviations: EGP, endogenous glucose production; HFLCT, high fat longchain triacylglycerol; HFMCT, high fat medum-chain triacylglycerol; LCFA, long-chain fatty acid; LF, low fat; MCFA, medium-chain fatty acid; Rd, glucose rate of disappearance.

Supported by TI food and Nutrition (Wageningen, The Netherlands). The study sponsor was not involved in the design or performance of the study.

* Corresponding author. Department of Human Genetics, Leiden University Medical Center, 2300 RC Leiden, The Netherlands. Tel.: + 31 0715269470; fax: +310715268285

E-mail address: kowvd@lumc.nl (K.W. van Dijk).

${ }^{1}$ These authors contributed equally. ability of insulin to promote peripheral glucose disposal and suppress hepatic glucose output. It is currently believed that insulin resistance is predominantly a life style disorder with diet composition as one of the major determinants. Results from both epidemiological and animal studies suggest that the risk of developing insulin resistance is increased by consumption of a high-fat (HF) diet [2]. It is observed that lipids not only increase body weight but also accumulate outside the adipose depots in for example; muscle, liver and heart [3]. This ectopic fat accumulation has been suggested to be directly or indirectly responsible for an impaired insulin signaling and the development of insulin resistance [4]. Indeed, multiple studies have shown that mixtures of long chain fatty acids varying in the degree of saturation originating from palm oil, lard, olive oil, corn oil or safflower oil, negatively affect insulin sensitivity [5-8], paralleled by an increase in ectopic fat accumulation [5,6].

Medium chain triacylglycerols are fats comprised of fatty acids with a chain length of 6-12 carbons and found predominantly in 
coconut oil and dairy products. Medium chain fatty acids (MCFA) differ in several aspects from long chain fatty acids; (a) their shorter chain length renders them water-soluble in the intestinal lumen and in the cytoplasm of target cells, (b) they are absorbed predominantly via the portal vein into the liver bypassing the lymphatic system [9] and (c) they are rapidly beta-oxidized [10] due to their independence of mitochondrial carnitine palmitoyl transferase 1 , which is a fatty acid transporter and one of the rate limiting steps for mitochondrial beta oxidation.

Several studies have confirmed an increased fat oxidation and whole body energy expenditure in humans after 7-28 days diet intervention with medium chain fatty acids $[11,12]$. Since MCFA are preferentially oxidized, we questioned whether a HF diet rich in medium chain fatty acids would lead to less accumulation of fat in the skeletal muscle and the liver and thereby not impair insulin sensitivity. Therefore, we here examined if long-term substitution of medium chain triacylglycerols by long chain triacylglycerols in an isocaloric diet with similar amounts of proteins, fat and carbohydrates increases whole body fat oxidation and prevents long chain HF diet induced and insulin resistance of skeletal muscle and liver.

\section{Materials and methods}

\subsection{Animals, diets and housing}

Male C57bl/6J mice were obtained from Charles River Laboratories at an age of 8 weeks and acclimatized up to an age of 12 weeks at the Leiden University Medical Centre animal facility. Animals were housed individually in a controlled environment $\left(23^{\circ} \mathrm{C}, 40-50 \%\right.$ humidity) under a $12 \mathrm{~h}$ light-dark cycle (07:00-19:00). Food and tap water was available ad libitum during the entire experiment. After acclimatization mice were randomized and kept on a low-fat (LF) diet $[13,14]$ (RM3, Special Diet Services, Witham, Essex, UK) (Table 1), or a HF diet either rich in long-chain triacylglycerol (HFLCT) or medium-chain triacylglycerols (HFMCT) (45\% energy in the form of fat, LCT; 4031.17, MCT; 4031.16, Hope Farms, Woerden, The Netherlands) (Table 1). The fatty acid composition of the diets is shown in Table 2. All animal experiments were approved by the Animal Ethic Committee from the Leiden University Medical Center in accordance with the principles and guidelines established by the European Convention for the Protection of Laboratory Animals.

\subsection{Indirect calorimetry}

Groups of eight mice per HF diet were subjected to individual indirect calorimetric measurements (Comprehensive Laboratory Animal Monitoring System, Columbus Instruments, Columbus Ohio, US) for a period of 4 consecutive days after 1 and 8 weeks of diet intervention [36,37]. A period of $24 \mathrm{~h}$ was included at the start of the experiment to allow acclimatization of the animals to the cages. This period was not used in the calculation and interpretation of the results. Oxygen consumption $\left(\mathrm{VO}_{2}\right)$ and carbon dioxide production rates $\left(\mathrm{VCO}_{2}\right)$ were measured at intervals of 7 minutes. Fat and carbohydrate oxidation rates were calculated from $\mathrm{VO}_{2}$ and $\mathrm{VCO}_{2}$ using the following formulas:

Carbohydrate oxidation $(\mathrm{kcal} / \mathrm{h})=\left(\left(\left(4.585 * \mathrm{VO}_{2}\right)-\left(3.226 * \mathrm{VO}_{2}\right)\right) * 4\right) / 1000$

Fat oxidation $(\mathrm{kcal} / \mathrm{h})=\left(\left(\left(1.695 * \mathrm{VO}_{2}\right)-\left(1.701 * \mathrm{VO}_{2}\right)\right) * 9\right) / 1000$

Total energy expenditure was calculated from the sum of carbohydrate and fat oxidation. Measured parameters also included real time food intake and activity, which was monitored as two-dimensional infrared beam breaks.

Table 1

Macronutrient composition of the diets

\begin{tabular}{lccc}
\hline Ingredients & LF & HFLCT & HFMCT \\
\hline & $g / k g$ & & \\
Protein & 212 & 211 & 211 \\
Carbohydrate & 492 & 383 & 383 \\
Fat & 53 & 250 & 250 \\
Fiber & 46 & 61 & 61 \\
& & & \\
Energy & $M J / k g$ & 19.7 & 19.7 \\
\hline
\end{tabular}

Table 2

Percentages of fatty acids in the diets

\begin{tabular}{lccc}
\hline Percentage fatty acids of total lipids & LF & HFLCT & HFMCT \\
\hline C8:0 & $\%$ & & \\
C10:0 & - & - & 37 \\
C14:0 & - & - & 55 \\
C16:0 & 1 & 1 & - \\
C18:0 & 16 & 75 & 1 \\
C18:1 & 3 & 6 & - \\
C18:2 & 19 & 13 & 4 \\
C18:3 & 48 & 4 & 1 \\
Other & 5 & 1 & - \\
\hline
\end{tabular}

All fatty acids are a percentage of total composition.

\subsection{Net caloric intake}

Feces were also collected during the stay in the metabolic cages in week 8. Feces were lyophilized and analyzed for energy content using adiabatic bomb calorimetry (Ikacalorimeter system C4000 Heitersheim, Germany). Net caloric intake by the animal was calculated by subtraction of the energy content of the feces from the gross dietary energy intake.

\subsection{Histological analysis of intramyocellular and intrahepatic lipids}

Cryosections $(5 \mu \mathrm{m})$ from the liver and the midbelly region of the gastrocnemius muscle were stained for neutral lipids with Oil red 0 [15] and quantified as previously described [16].

\subsection{Hyperinsulinemic euglycemic clamp}

Hyperinsulinemic euglycemic clamps were performed as described before [17-21], with minor modifications. Clamp experiments were performed after an overnight fast and under anesthesia by intraperitoneal injection with a combination of Acepromazin ( $0.5 \mathrm{mg} / \mathrm{kg}$, Sanofi Santé Nutrition Animale, Libourne Cedex, France), Midazolam (0.25 $\mathrm{mg} / \mathrm{kg}$, Roche, Mijdrecht, The Netherlands) and Fentanyl (0.025 mg/kg, Janssen-Cilag, Tilburg, The Netherlands).

A continuous infusion of $\mathrm{D}-\left[1-{ }^{14} \mathrm{C}\right]$ glucose at a rate of $0.8 \mu \mathrm{Ci} / \mathrm{h}$ (specific activity, 9.6 GBq/mmol; Amersham, Little Chalfont, UK) in the tail vein was started and blood samples were taken to determine basal glucose kinetics. After $60 \mathrm{~min}$, the mice received a bolus of insulin ( $4.5 \mathrm{mU}$, Actrapid; Novo Nordisk, Chartres, France) to initiate the hyperinsulinaemic state followed by constant infusion of insulin $(3.5 \mathrm{mU} /$ $\mathrm{kg}$ per minute). Infusion of $\mathrm{D}-\left[1-{ }^{14} \mathrm{C}\right]$ glucose was continued at a rate of $0.8 \mu \mathrm{Ci} / \mathrm{h}$ and a variable infusion of D-glucose $(12.5 \% \mathrm{w} / \mathrm{v}$ in phosphate-buffered saline) was used to maintain blood glucose levels at basal levels (euglycemia). Blood glucose was monitored via tail bleeding with a hand glucose meter (AccuCheck, Roche Diagnostics, Metronic Medical Systems, Vianen, The Netherlands) every 10 min to adjust the glucose infusion rate. After reaching steady state, blood samples were taken at 10-min intervals during $30 \mathrm{~min}$ to determine levels of $\mathrm{D}-\left[1-{ }^{14} \mathrm{C}\right]$ glucose. An average clamp experiment took approximately $2.5 \mathrm{~h}$, and anesthesia as well as body temperature was maintained throughout the procedure. Immediately after the last blood sample the mice were killed by cervical dislocation and hindlimb skeletal muscles and liver were dissected and frozen in liquid nitrogen-cooled isopentane and stored at $-80^{\circ} \mathrm{C}$ until further analyses.

\subsection{Analysis of clamp samples}

To measure plasma D- $\left[1-{ }^{14} \mathrm{C}\right]$ glucose activity, trichloroacetic acid (final concentration $2 \%$ ) was added to $7.5 \mu$ plasma to precipitate proteins using centrifugation. The supernatant was dehydrated and resuspended in milliQ. The samples were counted using scintillation counting (Packard Instruments, Dowers Grove, IL, USA).

\subsection{Calculations}

The glucose turnover rate ( $\mu \mathrm{mol} \mathrm{min}^{-1} \mathrm{~kg}^{-1}$ ) was calculated during the basal period and under steady-state clamp conditions as the rate of tracer infusion (dpm/ min) divided by the plasma specific activity of $\mathrm{D}-\left[1-{ }^{14} \mathrm{C}\right]$ glucose $(\mathrm{dpm} / \mu \mathrm{mol})$. This ratio was corrected for total body mass. The hyperinsulinemic endogenous glucose production was calculated as the difference between the tracer-derived rate of glucose appearance and the glucose infusion rate.

\subsection{Statistics}

All data derived from the experiments were analyzed using the SPSS 15.0 package. Indirect calorimetry and net caloric intake was tested using 2-sided unpaired t-tests for normally distributed data. When comparing three groups analysis of variance (ANOVA) was used to calculate for significant differences between groups and 
A

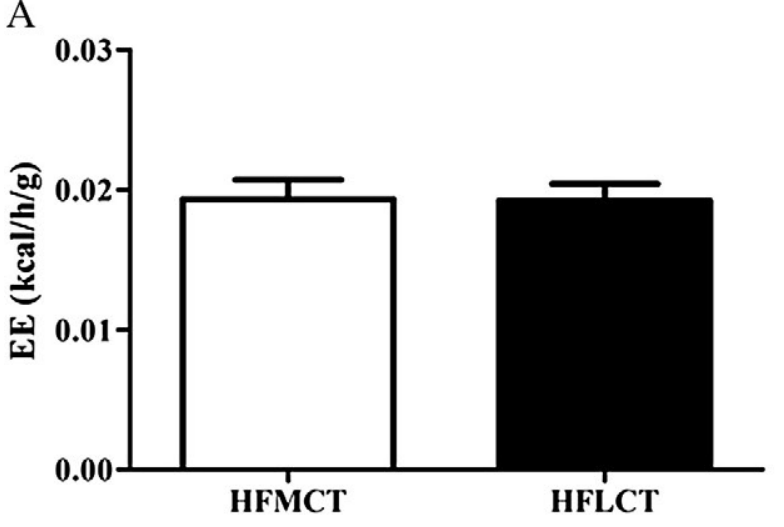

C

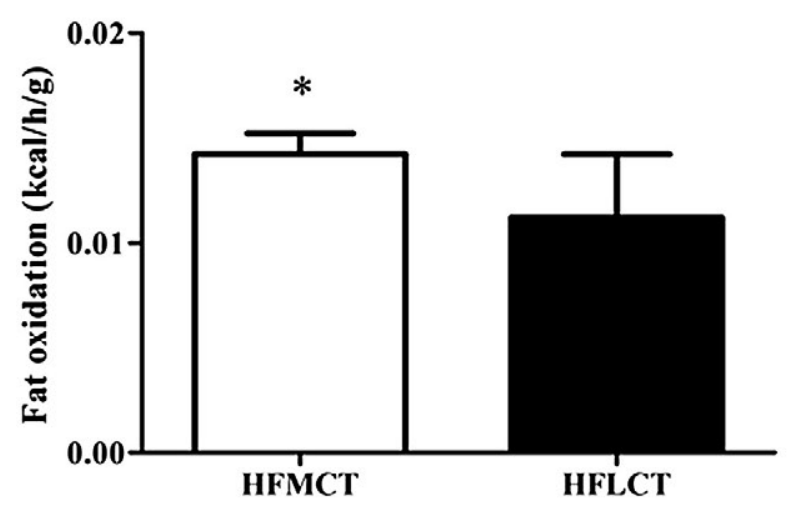

E

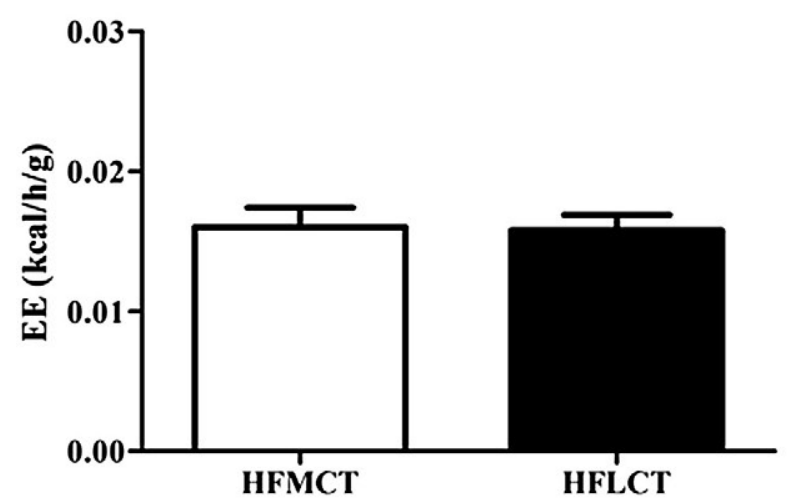

G

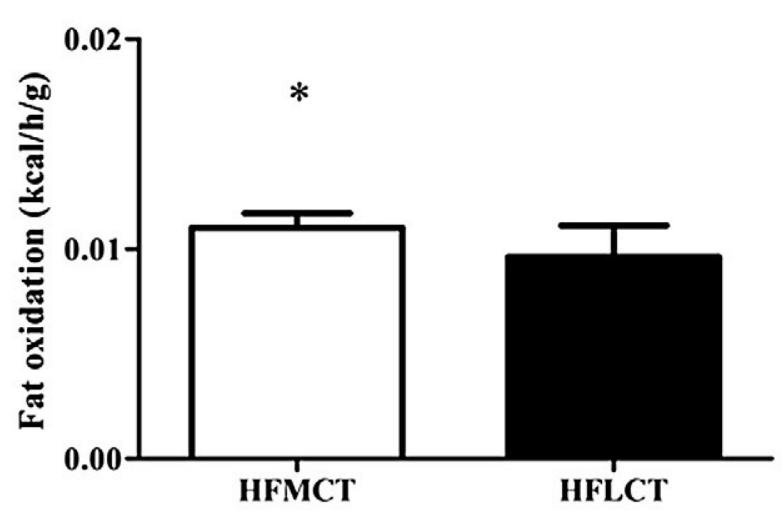

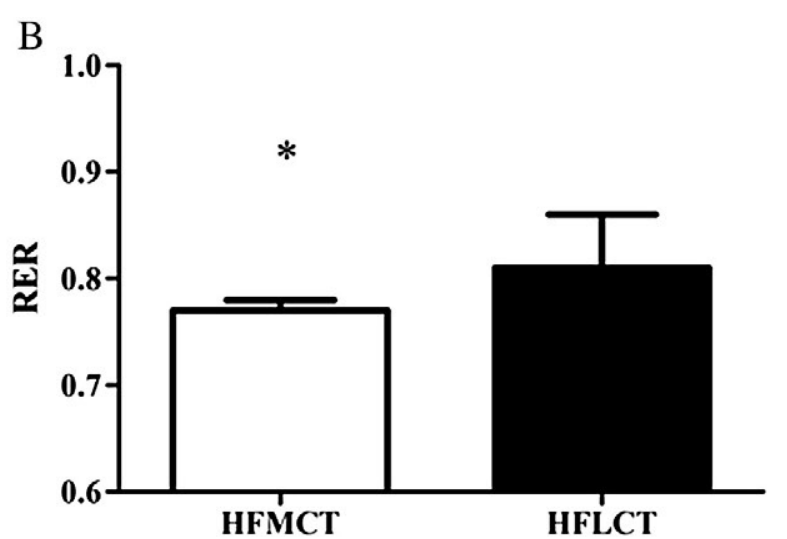

$\mathrm{D}$

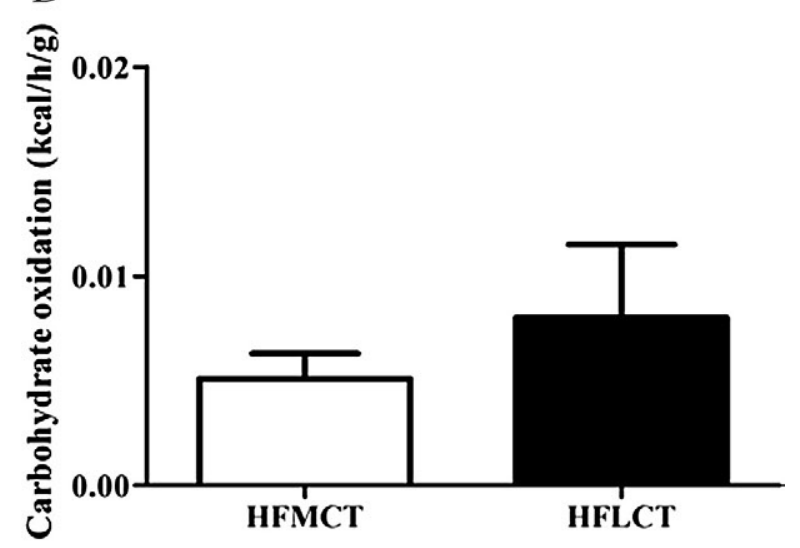

F

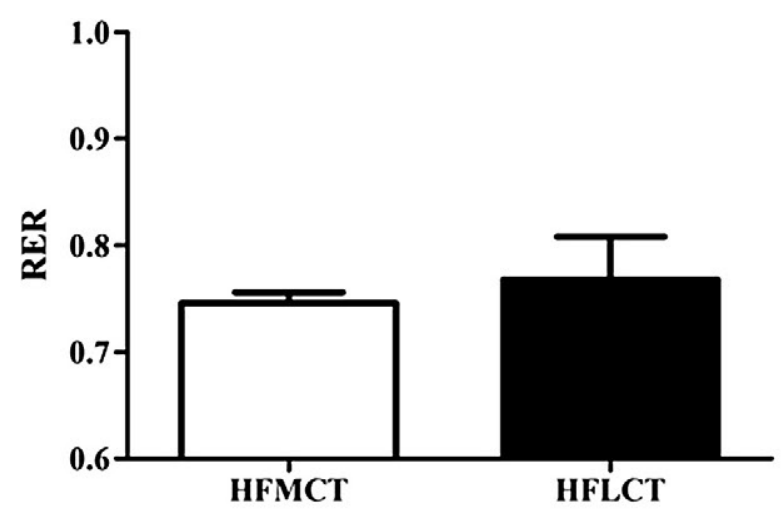

$\mathrm{H}$

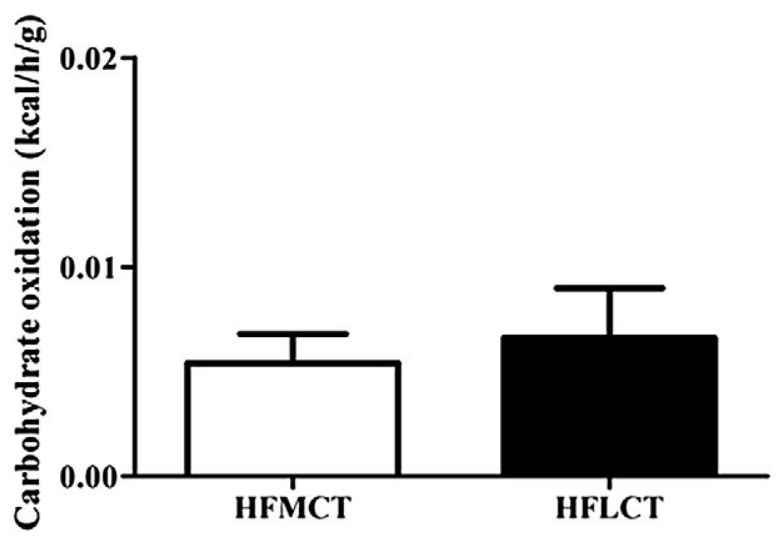


additional LSD post hoc tests to define the significance between groups. If ANOVA assumptions were violated, the results were tested with non-parametric KruskalWallis ANOVA and Mann-Whitney $U$ post hoc tests. All results are expressed as means \pm S.D. Statistical significance threshold was set at $P<.05$.

\section{Results}

\subsection{Body weight and net caloric intake}

Adult 12-week old male C57Bl/6 mice were maintained on a lowfat (LF) diet or transferred to a HF diet, enriched in triacylglycerols composed of long-chain fatty acids (HFLCT) or MCFAs (HFMCT) for a period of 8 weeks. At the end of the study, all HF-fed mice gained weight compared to the start of the experiment. After 8 weeks of diet intervention, body weight gain of the HF-fed mice was significantly higher compared to the LF-fed mice $(P<.02)$ (LF, $1.8 \pm 1.5 \mathrm{~g}$; HFLCT, $5.6 \pm 1.4 \mathrm{~g} ; \mathrm{HFMCT}, 3.8 \pm 1.9)$. In addition, HFMCT mice gained significantly less weight compared to the HFLCT fed mice $(P<.05)$. Total caloric intake over $70 \mathrm{~h}$, determined during the metabolic cage analysis, was significantly lower in the HFMCT compared to HFLCTfed animals at Week 1 (HFMCT, $1.84 \pm 0.24 \mathrm{kcal} / \mathrm{g}$; HFLCT, $3.11 \pm 0.49$ $\mathrm{kcal} / \mathrm{g} ; P<.01$ ) and at Week 8 (HFMCT, $2.13 \pm 0.34 \mathrm{kcal} / \mathrm{g} ;$ HFLCT, $2.80 \pm 0.48 \mathrm{kcal} / \mathrm{g} ; P<.05)$. Caloric content of the feces collected during the stay in the metabolic cage in week 8 was significantly lower in the HFMCT compared to the HFLCT-fed mice (HFMCT, $0.16 \pm 0.03 \mathrm{kcal} / \mathrm{g}$; HFLCT, $0.35 \pm 0.09 \mathrm{kcal} / \mathrm{g} ; P<.01$ ), which represented $\sim 7.5 \%$ and $\sim 12.3 \%$ of total caloric intake. Despite the higher fecal caloric output of the HFLCT-fed animals, net caloric intake was still significantly higher in the HFLCT-fed animals compared to the HFMCT-fed mice (HFLCT, $2.5 \pm 0.4 \mathrm{kcal} / \mathrm{g}$; HFMCT, $2.0 \pm 0.3 \mathrm{kcal} / \mathrm{g} ; P<.02$ ).

\subsection{Indirect calorimetry}

Indirect calorimetry measurements were applied to examine whole body substrate utilization of the HF-fed mice during 3 consecutive days in Weeks 1 and 8. Total energy expenditure was similar in both HF diets after one $(P=1.0)$ or 8 weeks $(P=.8)$ of dietary intervention (Fig. $1 \mathrm{~A}$ and $\mathrm{E}$ ). However, mean 24-h respiratory exchange rate (RER, defined as $\mathrm{VCO}_{2} / \mathrm{VO}_{2}$ ) in HFMCT-fed animals was significantly lower compared to HFLCT-fed animals in week 1 $(P=.05)$ (Fig. 1B). In week 8, 24 h RER values tended to be lower in HFLCT-fed mice $(P=.07)$ (Fig. 1F). These results indicate that HFMCTfed animals have a HF to carbohydrate oxidation ratio compared to HFLCT-fed animals. Indeed, when calculating the $24 \mathrm{~h}$ fat and carbohydrate oxidation levels, a higher $24 \mathrm{~h}$ fat oxidation rate was found in HFMCT-fed mice in both week $1(P=.03)$ and week $8(P=.02)$ (Fig. $1 C$ and $G)$.

Calculated $24 \mathrm{~h}$ carbohydrate oxidation rates were not significantly different between HFMCT and HFLCT-fed mice at week 1 $(P=.07)$ or week $8(P=.4)$ (Fig. $1 \mathrm{D}$ and $\mathrm{H})$. These data indicate that MCT feeding leads to higher relative and absolute fat oxidation levels compared to LCT feeding.

\subsection{Ectopic lipid accumulation}

To determine whether HFMCT and HFLCT diets resulted in differential ectopic lipid accumulation Oil red $\mathrm{O}$ staining of skeletal muscle and liver was performed (Supplementary Figs. 1 and 2). These experiments showed that the mice fed the HF diet enriched for MCT had significantly lower levels of intramyocellular lipid content compared to the HFLCT $(P<.03$, Fig. $2 A)$. Staining of liver sections revealed a similar response with a significantly lower level of lipids in the HFMCT group compared to the HFLCT group $(P<.002$, Fig. $2 \mathrm{~B})$. Intramyocellular and intrahepatic lipid content in the LF-fed mice was very low and just above detection limits (Fig. 2A and B).
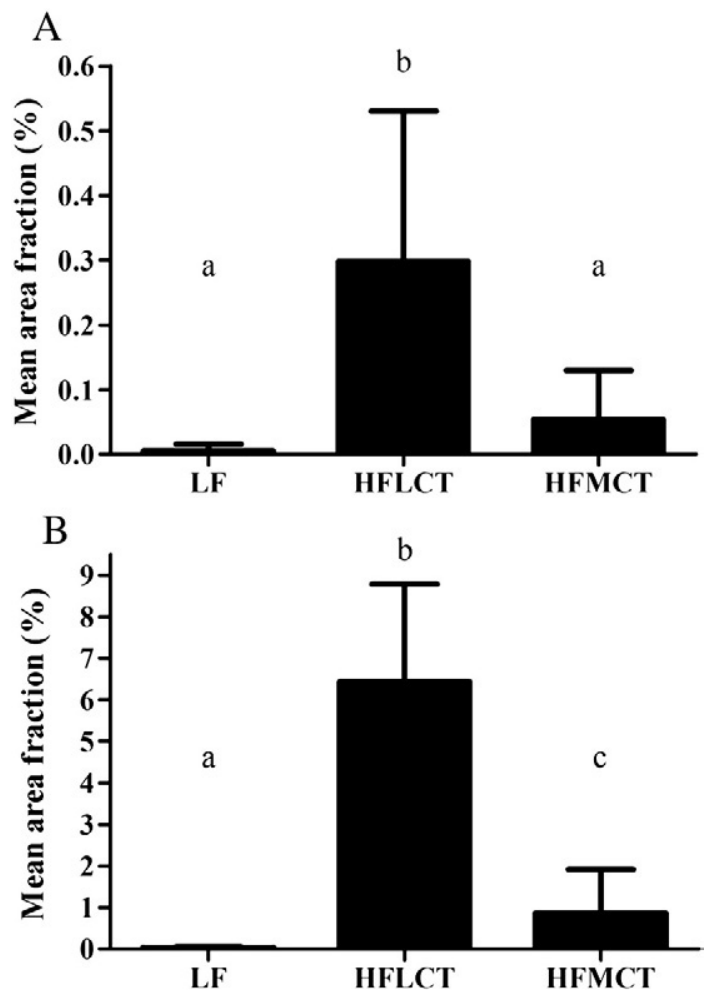

Fig. 2. Effects of an 8-week intervention with a LF, HFLCT or HFMCT diet on intramyocellular lipid content of the hind limb skeletal muscle (A) and the intrahepatic lipid content (B). Area fraction represents the percentage of the total muscle cell or liver area covered by lipid droplets. (mean \pm S.D., $n=3-8$, bars with different letters are significantly different, $P<.05$ )

\subsection{Hyperinsulinemic-euglycemic clamp}

To determine the effect of the HFMCT and HFLCT diets on wholebody glucose metabolism, hyperinsulinemic euglycemic clamps were performed in combination with continuous infusion of $D-\left[{ }^{14} \mathrm{C}\right]$ glucose. From these experiments peripheral and liver insulin sensitivity can be calculated separately. Glucose infusion rates to maintain euglycemia during the clamp were not significantly different between both HF diets (Fig. 3), but both infusion rates were significantly lower compared to LF-fed mice $(P<.001$ for both HF groups vs. LF). Under basal conditions, glucose rate of disappearance (Rd) and endogenous glucose production (EGP) were not significantly different between groups (Fig. 4A and B).

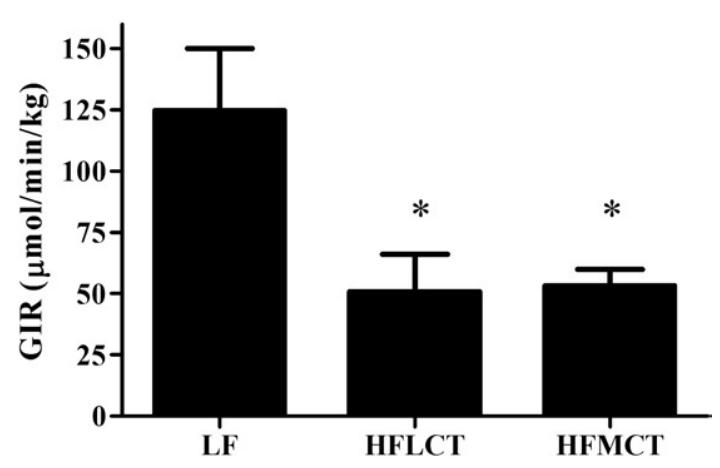

Fig. 3. Effects of an 8-week intervention with a LF, HFLCT or HFMCT diet on glucose infusion rate (GIR) during the hyperinsulinemic euglycemic clamp (mean \pm S.D., $n=6-10,{ }^{*} P<.001$; LF vs HF). 

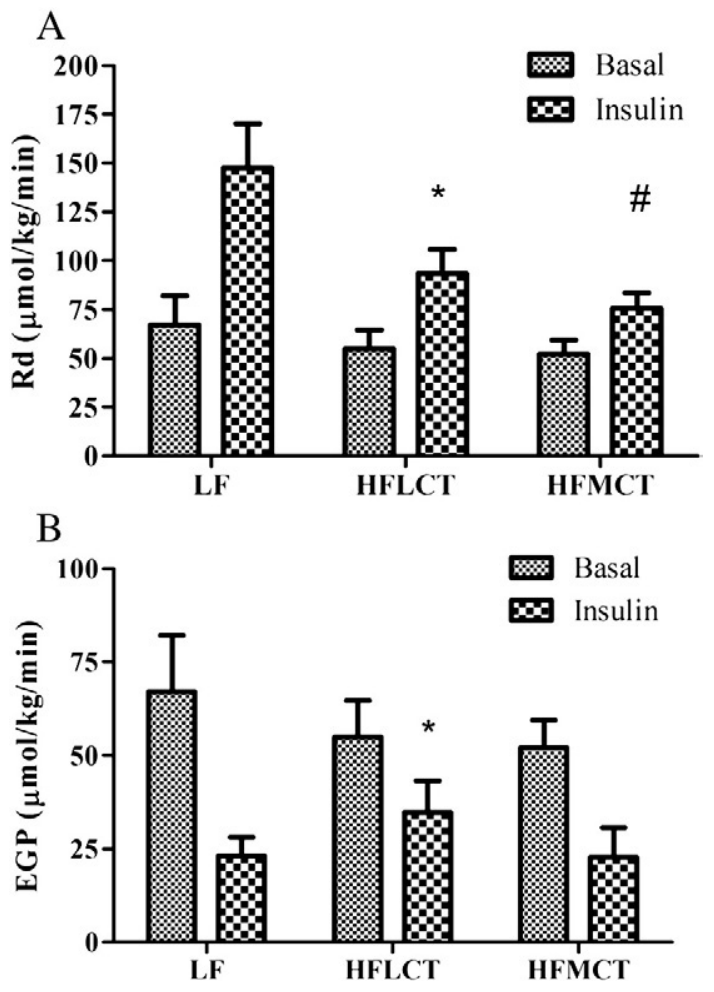

Fig. 4. Basal and insulin stimulated glucose disappearance rate (Rd) (A) and endogenous glucose production (EGP) (B) during the hyperinsulinemic euglycemic clamp (mean \pm S.D., $n=5-10,{ }^{*} P<.05$; HFLCT vs. LF and HFMCT; $\# P<.005$, HFMCT vs. LF compared to the respective diet within the insulin stimulated state).

During the hyperinsulinemic state, Rd was significantly lower in the HFMCT-fed group compared to the HFLCT group $(P<.03)$. Indicating impaired insulin sensitivity of the peripheral organs in the HFMCT compared to the HFLCT-fed mice. In addition, insulin stimulated Rd was significantly lower in both HF groups compared to the LF group $(P<.005)$ (Fig. 4A).

In contrast, endogenous glucose production under hyperinsulinemic conditions was significantly lower - indicating improved hepatic insulin sensitivity - in HFMCT compared to HFLCT $(P<.05)$. In addition, EGP in the HFLCT was significantly higher compared to LF $(P<.01)$ (Fig. 4B).

These results indicate that both HF diets induced insulin resistance, although under hyperinsulinemic conditions peripheral insulin sensitivity was more reduced by the HFMCT diet, whereas liver insulin sensitivity was only affected by the HFLCT diet.

\section{Discussion}

In the present study, we showed that diets rich in medium chain triacylglycerols have much lower levels of lipids in skeletal muscle and liver when compared to diets rich in long-chain triacylglycerols. However, surprisingly, both HF diets reduced whole body insulin sensitivity to a similar degree. Therefore, medium chain triacylglycerol diets have no beneficial effect on the maintenance of whole body glucose metabolism. Since there is a clear difference in the development of tissue-specific insulin resistance, the mechanisms underlying the development of insulin resistance may, however, differ between long- and medium-chain diets.

Whole body insulin resistance is associated with increased dietary fat intake $[2,22]$. Therefore, it would be an ideal strategy to modulate whole body insulin sensitivity via a change in food composition. In that context, MCT diets may be interesting. MCFAs are preferentially oxidized compared to long-chain fatty acids $[10,23,24]$, first, due to their fast transport directly to the liver via the portal vein $[9,25,26]$; second, MCFAs are directed towards oxidation since fatty acyl synthetase responsible for triacylglycerol re-esterification is most sensitive for FA with a chain length of 14 or more [26] and third, because their transport into mitochondria is predominantly carnitine-independent.

Since a disturbed balance in fat intake vs. oxidation has been associated with the development of insulin resistance and Type 2 diabetes, foods that stimulate fat oxidation or inhibit food intake would be expected to have beneficial effects on insulin sensitivity. Here, we indeed show an acute and long-term adaptation with an increased 24-h fat oxidation after a diet rich in medium chain triacylglycerols when compared to LCT diets, as determined in whole body metabolic cages. Furthermore, mice fed the HFMCT diet ate less than the HFLCT-fed mice. This HFMCT- induced lower food intake might be explained by the level of liver fatty acid oxidation. Friedman et al. [27] have proposed that a decreased liver fatty acid oxidation, which reduces hepatic energy production, stimulates feeding behavior. In addition, it has been shown that increasing liver fatty acid oxidation, with for example feeding medium chain triglycerides, decreased food intake [28-30]. In addition, combining medium chain triacylglycerols in a breakfast of healthy human volunteers also decreased food intake by a post absorptive mechanism [31]. In the current study, we observed a higher fatty acid oxidation in the HFMCT compared to the HFLCT-fed mice. Although we do not know if the observed high fatty acid oxidation is specific for the liver, the peripheral tissues or both, we expect that due to the metabolic properties of MCTs, fatty acid metabolism in the liver is at least increased, which might explain the lower food intake in the HFMCTfed mice.

The increased fat oxidation in combination with the lower net caloric intake of mice on the HFMCT diet compared to the HFLCT diet might explain the lower body weight gain. In contrast to previous reports [32,33], we did not observe any thermogenic effects of the HFMCT diets, as 24 h energy expenditure was comparable between HFLCT and HFMCT diets. More important, however, we confirmed our hypothesis that HF diets rich in medium chain fatty acids - in contrast to diets with a similar energy fat percentage in the form of long chain fatty acids - do not lead to the accumulation of lipids in skeletal muscle and liver. However, unexpectedly, both diets induced similar levels of whole body insulin resistance, when compared to LF diets. This illustrates that an accumulation of fat in liver and/or skeletal muscle is not a prerequisite for the development of whole-body insulin resistance.

Insulin-stimulated disappearance of glucose was lower in the HFMCT diet group when compared to the HFLCT diet group, whereas hepatic insulin sensitivity was reduced in the HFLCT but not in the HFMCT group. This indicates distinct regulation of the glucose metabolism in peripheral insulin sensitive tissues and the liver after both diets. In the HFLCT group, we speculate that whole body insulin sensitivity is impaired due to the ectopic accumulation of lipids that could interfere with insulin signaling in skeletal muscle and liver, as suggested previously [4]. The absence of hepatic insulin resistance in the HFMCT group fits with the concept that ectopic fat accumulation is associated with the development of insulin resistance, as the HFMCT diet, despite being high in fat content, did not result in the accumulation of fat in the liver. Most likely, HFMCT-induced peripheral insulin resistance is predominantly caused by a defect in glucose uptake in the skeletal muscles, given that skeletal muscle accounts for $~ 75-80 \%$ [34] of all insulin-mediated glucose uptake in the post prandial state. In that aspect, we can state that in the current model the induction of skeletal muscle insulin resistance by the HFMCT diet was not associated with accumulation of intramyocellular 
lipids. The relationship between fatty acid metabolism and the development of Type 2 diabetes mellitus has in recent years been mainly explained by the accumulation of fatty acids in skeletal muscle that could interfere with insulin signaling. Randle suggested three decades ago [35] that competition of lipid substrates with glucose could be responsible for the development of insulin resistance. The results of the present study may fit with that concept. We observed a higher rate of fat oxidation in the HFMCT compared to the HFLCT-fed mice at all time points measured. We speculate that this high fatty acid oxidation rate in HFMCT-fed animals is due to a higher fat oxidation rate in the liver and skeletal muscles. Medium chain triacylglycerols are rapidly available and preferentially oxidized compared to LCT $[10,23,24]$. The reduced peripheral uptake of glucose might be due to the contribution of the myocellular MCFA-derived acetyl-CoA to the total pool of acetyl-CoA, which could create a negative feedback loop via citrate accumulation on pyruvate dehydrogenase. This sequentially blocks the glycolytic pathway and ultimately results in reduced glucose uptake and oxidation and thereby to a reduced insulin stimulated uptake of glucose [35]. However, further exploration of these substrate fluxes requires additional studies.

Taken together, a HF diet rich in medium chain triacylglycerols is preferentially oxidized over long chain triacylglycerols, which resulted in a lower accumulation of lipids in the skeletal muscle and the liver of the mice. Surprisingly, both HF diets induced whole body insulin resistance, although the HFMCT had a lower peripheral insulin sensitivity and normal hepatic insulin sensitivity compared to the HFLCT-fed mice. This suggests that these diets induce insulin resistance via distinct mechanisms.

\section{Appendix A. Supplementary data}

Supplementary data associated with this article can be found, in the online version, at doi:10.1016/j.jnutbio.2010.03.004.

\section{References}

[1] Zimmet P, Alberti KG, Shaw J. Global and societal implications of the diabetes epidemic. Nature 2001;414(6865):782-7.

[2] Lichtenstein AH, Schwab US. Relationship of dietary fat to glucose metabolism. Atherosclerosis 2000;150(2):227-43.

[3] van Herpen NA, Schrauwen-Hinderling VB. Lipid accumulation in non-adipose tissue and lipotoxicity. Physiol Behav 2008;94(2):231-41.

[4] Muoio DM, Newgard CB. Mechanisms of disease: molecular and metabolic mechanisms of insulin resistance and beta-cell failure in Type 2 diabetes. Nat Rev Mol Cell Biol 2008;9(3):193-205.

[5] Buettner R, Parhofer KG, Woenckhaus M, Wrede CE, Kunz-Schughart LA, Scholmerich J, et al. Defining high-fat-diet rat models: metabolic and molecular effects of different fat types. J Mol Endocrinol 2006;36(3):485-501.

[6] Storlien LH, Jenkins AB, Chisholm DJ, Pascoe WS, Khouri S, Kraegen EW. Influence of dietary fat composition on development of insulin resistance in rats. Relationship to muscle triglyceride and omega-3 fatty acids in muscle phospholipid. Diabetes 1991;40(2):280-9.

[7] Wilkes JJ, Bonen A, Bell RC. A modified high-fat diet induces insulin resistance in rat skeletal muscle but not adipocytes. Am J Physiol 1998;275(4 Pt 1):E679-86.

[8] Kraegen EW, Clark PW, Jenkins AB, Daley EA, Chisholm DJ, Storlien LH. Development of muscle insulin resistance after liver insulin resistance in highfat-fed rats. Diabetes 1991;40(11):1397-403.

[9] Bach AC, Ingenbleek Y, Frey A. The usefulness of dietary medium-chain triglycerides in body weight control: fact or fancy? J Lipid Res 1996;37(4):708-26.

[10] Leyton J, Drury PJ, Crawford MA. Differential oxidation of saturated and unsaturated fatty acids in vivo in the rat. Br J Nutr 1987;57(3):383-93.

[11] St-Onge MP, Ross R, Parsons WD, Jones PJ. Medium-chain triglycerides increase energy expenditure and decrease adiposity in overweight men. Obes Res 2003;11 (3):395-402.
[12] White MD, Papamandjaris AA, Jones PJ. Enhanced postprandial energy expenditure with medium-chain fatty acid feeding is attenuated after $14 \mathrm{~d}$ in premenopausal women. Am J Clin Nutr 1999;69(5):883-9.

[13] Taylor PD, Khan IY, Lakasing L, Dekou V, O'Brien-Coker I, Mallet AI, et al. Uterine artery function in pregnant rats fed a diet supplemented with animal lard. Exp Physiol 2003;88(3):389-98.

[14] Armitage JA, Ishibashi A, Balachandran AA, Jensen RI, Poston L, Taylor PD. Programmed aortic dysfunction and reduced $\mathrm{Na}+, \mathrm{K}+-$-ATPase activity present in first generation offspring of lard-fed rats does not persist to the second generation. Exp Physiol 2007;92(3):583-9.

[15] Koopman R, Schaart G, Hesselink MK. Optimisation of oil red O staining permits combination with immunofluorescence and automated quantification of lipids. Histochem Cell Biol 2001;116(1):63-8.

[16] Hoeks J, Briede JJ, de Vogel J, Schaart G, Nabben M, Moonen-Kornips E, et al. Mitochondrial function, content and ROS production in rat skeletal muscle: effect of high-fat feeding. FEBS Lett 2008;582(4):510-6.

[17] den Boer MA, Voshol PJ, Kuipers F, Romijn JA, Havekes LM. Hepatic glucose production is more sensitive to insulin-mediated inhibition than hepatic VLDLtriglyceride production. Am J Physiol Endocrinol Metab 2006;291(6):E1360-4.

[18] Goudriaan JR, Dahlmans VE, Teusink B, Ouwens DM, Febbraio M, Maassen JA, et al. CD36 deficiency increases insulin sensitivity in muscle, but induces insulin resistance in the liver in mice. J Lipid Res 2003;44(12):2270-7.

[19] Duivenvoorden I, Teusink B, Rensen PC, Romijn JA, Havekes LM, Voshol PJ. Apolipoprotein C3 deficiency results in diet-induced obesity and aggravated insulin resistance in mice. Diabetes 2005;54(3):664-71.

[20] van den Hoek AM, Teusink B, Voshol PJ, Havekes LM, Romijn JA, Pijl H. Leptin deficiency per se dictates body composition and insulin action in ob/ob mice. J Neuroendocrinol 2008;20(1):120-7.

[21] Voshol PJ, Jong MC, Dahlmans VE, Kratky D, Levak-Frank S, Zechner R, et al. In muscle-specific lipoprotein lipase-overexpressing mice, muscle triglyceride content is increased without inhibition of insulin-stimulated whole-body and muscle-specific glucose uptake. Diabetes 2001;50(11):2585-90.

[22] Defronzo RA. Banting lecture. From the triumvirate to the ominous octet: a new paradigm for the treatment of Type 2 diabetes mellitus. Diabetes 2009;58(4): 773-95.

[23] DeLany JP, Windhauser MM, Champagne CM, Bray GA. Differential oxidation of individual dietary fatty acids in humans. Am J Clin Nutr 2000;72(4):905-11.

[24] Metges CC, Wo ram G. Medium- and long-chain triglycerides labeled with 13C: a comparison of oxidation after oral or parenteral administration in humans. J Nutr 1991;121(1):31-6.

[25] McDonald GB, Saunders DR, Weidman M, Fisher L. Portal venous transport of long-chain fatty acids absorbed from rat intestine. Am J Physiol 1980;239(3): G141-50.

[26] Papamandjaris AA, MacDougall DE, Jones PJ. Medium chain fatty acid metabolism and energy expenditure: obesity treatment implications. Life Sci 1998;62(14): 1203-15.

[27] Friedman MI, Harris RB, Ji H, Ramirez I, Tordoff MG. Fatty acid oxidation affects food intake by altering hepatic energy status. Am J Physiol 1999;276(4 Pt 2): R1046-53.

[28] Ooyama K, Kojima K, Aoyama T, Takeuchi H. Decrease of food intake in rats after ingestion of medium-chain triacylglycerol. J Nutr Sci Vitaminol (Tokyo) 2009;55 (5):423-7.

[29] Jambor de Sousa UL, Arnold M, Langhans W, Geary N, Leonhardt M. Caprylic acid infusion acts in the liver to decrease food intake in rats. Physiol Behav 2006;87(2): 388-95.

[30] Friedman MI. Fuel partitioning and food intake. Am J Clin Nutr 1998;67(3 Suppl): 513S-8S.

[31] Van Wymelbeke V, Himaya A, Louis-Sylvestre J, Fantino M. Influence of mediumchain and long-chain triacylglycerols on the control of food intake in men. Am J Clin Nutr 1998;68(2):226-34.

[32] Hoeks J, Hesselink MK, van Bilsen M, Schaart G, van der Vusse GJ, Saris WH, et al. Differential response of UCP3 to medium versus long chain triacylglycerols; manifestation of a functional adaptation. FEBS Lett 2003;555(3):631-7.

[33] Baba N, Bracco EF, Hashim SA. Enhanced thermogenesis and diminished deposition of fat in response to overfeeding with diet containing medium chain triglyceride. Am J Clin Nutr 1982;35(4):678-82.

[34] DeFronzo RA, Jacot E, Jequier E, Maeder E, Wahren J, Felber JP. The effect of insulin on the disposal of intravenous glucose. Results from indirect calorimetry and hepatic and femoral venous catheterization. Diabetes 1981;30(12):1000-7.

[35] Randle PJ, Garland PB, Hales CN, Newsholme EA. The glucose fatty-acid cycle. Its role in insulin sensitivity and the metabolic disturbances of diabetes mellitus. Lancet 1963;1(7285):785-9.

[36] van den Berg SAA, Guigas B, Bijland S, Ouwens DM, Voshol PJ, Frants RR, et al. High levels of dietary stearate promote adiposity and deteriorate hepatic insulin sensitivity. Nutr Metab 2010;27:7-24.

[37] van den Berg SAA, Nabben M, Bijland S, Voshol PJ, van Klinken JB, Havekes LM, et al. High levels of whole body energy expenditure are associated with a lower coupling of skeletal muscle mitochondria in C57Bl/6 mice. Metabolism 2010 [Epub ahead of print]. 